\title{
Komposisi Asam Lemak, Angka Peroksida, dan Angka TBA Fillet Ikan Kakap (Lutjanus sp) pada Suhu dan Lama Penyimpanan Berbeda
}

\author{
Fatty Acid Composition, Peroxide Value, and TBA Value of Snapper (Lutjanus sp) fillet at Different Storage \\ Temperature and Time \\ Rahim Husain ${ }^{1 *}$, Suparmo ${ }^{2}$, Eni Harmayani ${ }^{2}$, Chusnul Hidayat ${ }^{2}$ \\ ${ }^{1}$ Fakultas Perikanan dan Ilmu Kelautan, Universitas Negeri Gorontalo, \\ Jl. Jenderal Sudirman, No. 6, Kota Gorontalo 96182, Indonesia \\ ${ }^{2}$ Departemen Teknologi Pangan dan Hasil Pertanian, Fakultas Teknologi Pertanian, Universitas Gadjah Mada, \\ Jl. Flora No. 1, Bulaksumur, Yogyakarta 55281, Indonesia \\ Email: imrahim76@yahoo.co.id
}

Submisi: 12 Mei 2016 ; Penerimaan: 11 Agustus 2016

\begin{abstract}
ABSTRAK
Ikan memiliki nilai gizi tinggi dan merupakan sumber makanan utama di banyak negara. Lipid ikan memiliki kandungan tinggi asam tak jenuh ganda (Poly Unsaturated Fatty Acid, PUFA), terutama asam eikosapentanoat (EPA; 20:5n-3) dan asam docosahexsanoat (DHA; 22:6n-3). Penelitian ini bertujuan untuk mengetahui komposisi asam lemak fillet ikan kakap (Lutjanus sp) dan kerusakan akibat proses penyimpanan. Hasil analisis asam lemak jenuh (Saturated Fatty Acid, $S F A$ ) menunjukkan bahwa asam lemak jenuh meningkat dari 4,35\% menjadi 25,55\%, 28,06\%, 32,73\%, dan $61,75 \%$ selama penyimpanan pada $0{ }^{\circ} \mathrm{C}, 10{ }^{\circ} \mathrm{C}, 20^{\circ} \mathrm{C}, 30^{\circ} \mathrm{C}$, dan $40^{\circ} \mathrm{C}$. Total asam lemak tak jenuh (Mono Unsaturated Fatty Acid, MUFA) adalah $23,72 \%, 23,69,14,4 \%, 22,66 \%$, dan $29,4 \%$ pada penyimpanan $0{ }^{\circ} \mathrm{C}, 10^{\circ} \mathrm{C}, 20^{\circ} \mathrm{C}, 30^{\circ} \mathrm{C}$, dan 40 ${ }^{\circ} \mathrm{C}$. Sedangkan total PUFA turun dari $25,05 \%$ menjadi $15,98 \%, 14,99 \%, 10,32 \%$, dan $8,84 \%$ pada penyimpanan $0{ }^{\circ} \mathrm{C}$, $10{ }^{\circ} \mathrm{C}, 20{ }^{\circ} \mathrm{C}, 30{ }^{\circ} \mathrm{C}$, dan $40{ }^{\circ} \mathrm{C}$. Angka peroksida sebagai produk primer dari oksidasi fillet ikan kakap meningkat 10,6 kali dengan kenaikan suhu dari $0{ }^{\circ} \mathrm{C}$ sampai $40{ }^{\circ} \mathrm{C}$. Angka TBA meningkat 6,6 kali dari suhu $0{ }^{\circ} \mathrm{C}$ ke suhu $40{ }^{\circ} \mathrm{C}$ pada lama penyimpanan 45 hari.
\end{abstract}

Kata kunci: Komposisi asam lemak; fillet ikan kakap (Lutjanus sp); angka peroksida; angka TBA

\begin{abstract}
Fish has a high nutritional value and is a major food source in many countries. Fish lipid has a high content of polyunsaturated fatty acids (PUFAs), especially eicosapentaenoic acid (EPA; 20: 5n-3) and docosahexsanoic acid (DHA; 22: 6n-3). The objective of this research was to determine fatty acids composition of snapper (Lutjanus sp) fillet and its damage during the storage process. The results showed that total of the saturated fatty acids (SFA) increased from $4.35 \%$ to $25.55 \%, 28.06 \%, 32.73 \%$, and $61.75 \%$ during storage at $0{ }^{\circ} \mathrm{C}, 10{ }^{\circ} \mathrm{C}, 20^{\circ} \mathrm{C}, 30^{\circ} \mathrm{C}$, and $40{ }^{\circ} \mathrm{C}$, respectively. Total mono-unsaturated fatty acids (MUFA) were $23.72 \%, 23.69 \%, 14.4 \%, 22.66 \%$, and $29.4 \%$ at storage temperature of $0{ }^{\circ} \mathrm{C}, 10{ }^{\circ} \mathrm{C}, 20^{\circ} \mathrm{C}, 30{ }^{\circ} \mathrm{C}$, and $40{ }^{\circ} \mathrm{C}$. Total PUFA decreased from $25.06 \%$ to $15.98 \%, 14.99 \%, 10.32 \%$, and $8.84 \%$ at $0^{\circ} \mathrm{C}, 10^{\circ} \mathrm{C}, 20^{\circ} \mathrm{C}, 30^{\circ} \mathrm{C}$, and $40^{\circ} \mathrm{C}$. Peroxide value, as primary peroxide of snapper fillet, increased about 10.60 times with an increased in storage temperature from $0{ }^{\circ} \mathrm{C}$ to $40^{\circ} \mathrm{C}$. Value of TBA increased 6.60 times with an increased in temperature from $0{ }^{\circ} \mathrm{C}$ to $40{ }^{\circ} \mathrm{C}$ during 45 days.
\end{abstract}

Keywords: fatty acid composition; fillet snapper (Lutjanus sp); peroxide value; TBA value 


\section{PENDAHULUAN}

Secara umum ikan memiliki nilai gizi yang tinggi dan merupakan sumber makanan utama di banyak negara. Lemak ikan memiliki kandungan asam tak jenuh ganda (Poly Unsaturated Fatty Acid, PUFA) yang tinggi, terutama asam eikosapentanoat (EPA; 20: 5n-3) dan asam dokosaheksaenoat (DHA; 22: 6n-3) (Pazos dkk., 2005; Bayir dan Sirkecioglu, 2006). Pengolahan dengan cara pembekuan ikan telah digunakan selama ribuan tahun karena dapat menghasilkan kualitas produk yang tinggi (Persson dan Londahl, 2013).

Kualitas ikan yang dibekukan dipengaruhi oleh penurunan suhu produk sehingga ketika ikan dithawing tetap dapat dipertahankan kesegarannya (Kolbe dkk., 2004). Namun, selama penyimpana ikan dan produk perikanan dapat mengalami perubahan yang tidak diinginkan sehingga dapat membatasi waktu penyimpanan. Perubahan tersebut diantaranya adalah oksidasi protein (Fijuwara dkk., 2008; Benjakul dkk., 2005) dan oksidasi lipid (Sarma dkk., 2000; Richards dan Hultin, 2012).

Degradasi asam lemak tak jenuh ganda (Poly Unsaturated Fatty Acid, PUFA) oleh oksidasi lipid selama penyimpanan menyebabkan pembentukan volatil yang terkait dengan ketengikan (Pazos dkk., 2005). Tingginya tingkat lemak tak jenuh membuat jaringan ikan sangat rentan terhadap peroksidasi dan cepat rusak. Perubahan oksidatif terutama terkait dengan rasa dan tekstur ikan. Perubahan warna, nilai gizi atau produk sekunder dari lipid akan teramati pada stadium lanjut dari proses peroksidasi lipid (Dragoev dkk., 2008).

Oksidasi lipid ikan biasanya didasarkan pada analisis indeks bias, nilai peroksida (Peroxide Value, PV) dan zat reaktif asam 2-thiobarbituric (TBARS) sebagai indikator produk oksidasi primer dan sekunder (Aranda dkk., 2005; Chaijan dkk., 2006; Pourashouri dkk., 2009; Quitral dkk., 2009; Seed dan Howell 2002; Yerlikaya dan Gokoglu, 2010). Penelitian ini bertujuan untuk mengetahui komposisi asam lemak fillet ikan kakap (Lutjanus $s p$ ) dan kerusakan selama penyimpanan.

\section{METODE PENELITIAN}

\section{Bahan Baku}

Bahan baku yang digunakan adalah ikan kakap (Lutjanus sp) yang diperoleh dari tempat pelelangan ikan (TPI) kobong, Kelurahan Kaligawe, Semarang, Jawa Tengah. Ikan dimasukkan ke dalam cool box yang berisi es, kemudian dibawa ke laboratorium dengan transportasi umum.

\section{Penyiapan Sampel Fillet Ikan}

Ikan kakap (Lutjanus sp) segar disiangi dan diambil dagingnya. Tulang, kelapa, insang, dan bagian tubuh lainnya dibuang. Daging ikan dicuci dan dibilas dengan air es untuk menghilangkan darah serta kotoran lain. Pembelahan ikan dilakukan mulai dari kepala ke ekor tanpa menyebabkan bagian punggung terpotong. Filleting dilakukan dengan cara penyayatan rusuk daging secara membujur sehingga menghasilkan daging tanpa tulang. Fillet ikan disimpan pada kotak penyimapanan atau inkubator yang telah disediakan di laboratorium pada suhu $0,10,20,30$, dan $40{ }^{\circ} \mathrm{C}$ selama 45 hari.

\section{Analisis Proksimat}

Analisis proksimat yang dilakukan meliputi kadar air, abu, protein dan lemak berdasarkan metode AOAC (2006).

\section{Prosedur Analisis Asam Lemak}

Prosedur analisis asam lemak menggunakan metode yang dikembangkan oleh Pirestani dkk, (2010)

\section{Hidrolisis}

Fillet ikan dicuci bersih dan dicincang sampai halus. Fillet cincang ditimbang sebanyak $\pm 10 \mathrm{~g}$ dan dihidrolisis dengan $10 \mathrm{~mL} \mathrm{HCl}$ pada suhu $70{ }^{\circ} \mathrm{C}$ selama 15 menit, lalu didinginkan. Selanjutnya, fillet diekstrak dengan $15 \mathrm{~mL}$ dietil eter dan $15 \mathrm{~mL}$ petroleum ether, lalu diambil lapisan atasnya. Fillet diekstrak lagi dengan $15 \mathrm{~mL}$ diethyl ether dan $15 \mathrm{~mL}$ petroleum eter, lalu lapisan atasnya diambil dan dijadikan satu dengan hasil sebelumnya. Ekstrak yang diperoleh kemudian diuapkan dalam waterbath dengan bantuan $\mathrm{N}_{2}$.

\section{Analisis asam lemak jenuh dan tidak jenuh}

Sebanyak 0,5 mL sampel ditambahkan kedalam 1,5 mL larutan natrium metanolik. Campuran dipanaskan pada suhu $70{ }^{\circ} \mathrm{C}$ selama 5-10 menit sambil digojok. Campuran kemudian didinginkan dan ditambah $2 \mathrm{~mL}$ Boron trifluorida metanoat selanjutnya dipanaskan pada suhu $70{ }^{\circ} \mathrm{C}$ selama 5-10 menit. Campuran didinginkan dan diekstrak dengan $1 \mathrm{~mL}$ hdan $1 \mathrm{~mL}$ $\mathrm{NaCl}$ jenuh. Lapisan atas diambil dan dimasukkan ke dalam Eppendorf. Sampel hasil ekstraksi sebanyak $1 \mu \mathrm{L}$ diinjeksikan ke Gas Chromatography (Shimadzu, 2010) yang dilengkapi dengan detector FID yang dioperasikan pada suhu $260{ }^{\circ} \mathrm{C}$. Kolom yang digunakan adalah CP Sil 8CB dengan panjang $30 \mathrm{~m}$. Profil oven yang digunakan adalah suhu awal $100{ }^{\circ} \mathrm{C}$ lalu dipertahankan selama 5 menit, kemudian suhu dinaikkan $4{ }^{\circ} \mathrm{C}$ per menit hingga $240{ }^{\circ} \mathrm{C}$, dan setelah mencapai suhu $240^{\circ} \mathrm{C}$ suhu dipertahankan selama 10 menit. 
Analisis angka peroksida (Hills dan Thiel, 1946 yang dimodifikasi Adnan, 1980)

Sampel (0,5 g) dimasukkan dalam tabung reaksi, kemudian ditambahkan $0,1 \mathrm{~mL}$ larutan ammonium tiosianat dan 0,1 $\mathrm{mL}$ larutan feroklorida. Tabung reaksi digojog selama 5 detik dan dipanaskan pada suhu $50{ }^{\circ} \mathrm{C}$ selama 2 menit, lalu didinginkan sampai suhu $25{ }^{\circ} \mathrm{C}$. Absorbansi ditera mengunakan spektrofotometer pada panjang gelombang 510 $\mathrm{nm}$. Larutan blangko dipreparasi menggunakan semua pelarut tanpa sampel.

\section{Analisis angka TBA (Tokur dan Korkmaz., 2007)}

Minyak 0,5 g ditambahkan $50 \mathrm{~mL}$ aquades, kemudian ditambahkan lagi $2,5 \mathrm{~mL} \mathrm{~N} \mathrm{HCl}$ setelah itu didestilasi. Tampung hasil destilasi sampai $50 \mathrm{~mL}$, ambil $5 \mathrm{~mL}$ hasil destilasi kemudian ditambahkan dengan $5 \mathrm{~mL}$ TBA. Setelah itu, dipanaskan selama 30 menit dan didinginkan. Absorbansi ditera pada panjang gelombang $528 \mathrm{~nm}$. Angka TBA dinyatakan dalam $\mathrm{mg}$ malonaldehid/ $\mathrm{kg}$ minyak.

\section{HASIL DAN PEMBAHASAN}

\section{Proksimat Ikan Kakap (Lutjanus sp)}

Berdasarkan Tabel 1 kadar lemak ikan kakap (Lutjanus $s p$ ) yang diperoleh dalam penelitian adalah 1,96\%. Nilai ini lebih tinggi dibandingkan dengan hasil yang dilaporkan oleh de Castro dkk. (2010) pada ikan nila tilapia (Oreochromis niloticus) yakni $0,79 \%$ dan tambagui (Colossoma macropomum) yakni 1,30\%. Tingginya kandungan lemak kasar pada ikan kakap (1,96\%) menunjukkan bahwa ikan kakap (Lutjanus sp) tergolong pada ikan yang mengandung lemak cukup tinggi.

Perbedaan kandungan lemak ikan sangat dipengaruhi oleh jenis ikan, ukuran ikan, musim penangkapan dan lingkungan dimana ikan hidup. Menurut Shaviklo (2006) ikan demersal mengandung lemak yang lebih tinggi dibanding

Tabel 1. Proksimat fillet ikan kakap (Lutjanus sp) dan kadar $\mathrm{Fe}$

\begin{tabular}{lr}
\hline \multicolumn{1}{c}{ Komposisi kimia } & \multicolumn{1}{c}{ Jumlah (\%) } \\
\hline Kadar air & $78,39 \pm 0,02$ \\
Kadar abu & $1,58 \pm 0,01$ \\
Protein & $18,77 \pm 0,02$ \\
Lemak & $1,96 \pm 0,01$ \\
Karbohidrat by difference & $0,30 \pm 0,01$ \\
Fe (ppm) & $108,95 \pm 0,03$ \\
\hline
\end{tabular}

Keterangan: nilai yang diperoleh berasal dari rata-rata 3 kali ulangan dengan ikan pelagis yang hidup di permukaan perairan. Ikan demersal biasanya hidup di dasar perairan dan jarang sekali melakukan aktivitas.

Tabel 1 juga menunjukkan bahwa ikan kakap (Lutjanus sp) mengandung Fe total sebesar 108,95 ppm. Menurut Grunwald dan Richard (2006) besi atau Fe dapat menyumbangkan kerusakan oksidasi pada lemak atau daging ikan selama penyimpanan. Fe dalam bentuk nonheme mempunyai kontribusi yang besar terhadap kerusakan oksidatif melalui jalur reaksi Fenton yakni $\mathrm{Fe}^{2+}+\mathrm{H}_{2} \mathrm{O}_{2}$ menjadi $\mathrm{Fe}^{3+}+\mathrm{OH}^{*}+\mathrm{OH}^{-}$.

\section{Komposisi Asam Lemak Fillet Ikan Kakap (Lutjanus sp)}

Tabel 2 adalah hasil analisis asam lemak fillet ikan kakap selama penyimpanan. Fillet ikan kakap memiliki asam lemak jenuh (Saturated Fatty Acid, SFA) yang terdiri dari: asam laurat, asam tridekanoat, asam meristat, asam pentadekanoat, asam palmitat, asam stearat, asam heneikosanoat, asam behenat, asam lignocerat, asam heptadekanoat, dan asam arakhidat. Total asam lemak jenuh meningkat dari 4,35\%, menjadi $25,55 \%, 28,06 \%, 32,73 \%$, dan $61,75 \%$ pada suhu 0 ${ }^{\circ} \mathrm{C}, 10{ }^{\circ} \mathrm{C}, 20{ }^{\circ} \mathrm{C}, 30^{\circ} \mathrm{C}$, dan $40{ }^{\circ} \mathrm{C}$.

Asam lemak tak jenuh tunggal (Mono Unsaturated Fatty Acid, MUFA) meliputi asam oleat, asam nervonat, asam palmitoleat, asam erucat, dan asam eikosanoat. Total asam lemak tak jenuh tunggal masing-masing adalah $23,72 \%$, $23,69 \%, 14,4 \%, 22,66 \%$, dan $29,40 \%$ pada penyimpanan suhu $0{ }^{\circ} \mathrm{C}, 10{ }^{\circ} \mathrm{C}, 20{ }^{\circ} \mathrm{C}, 30{ }^{\circ} \mathrm{C}$, dan $40{ }^{\circ} \mathrm{C}$. Sedangkan asam lemak tak jenuh majemuk (Poly Unsaturated Fatty Acid, PUFA) meliputi asam eikosatetranoat, asam dokosadinoat, asam eikosapentanoat, asam eikosatrioanat, asam arakidonat, dan asam linolenat. Total asam lemak tak jenuh majemuk adalah $25,06 \%, 15,98 \%, 14,99 \%, 10,32 \%$, dan $8,84 \%$ pada suhu penyimpanan $0{ }^{\circ} \mathrm{C}, 10^{\circ} \mathrm{C}, 20^{\circ} \mathrm{C}, 30^{\circ} \mathrm{C}$, dan $40^{\circ} \mathrm{C}$.

Beberapa peneliti menyatakan bahwa ikan yang disimpan dalam waktu yang cukup lama jumlah SFA akan meningkat (Nazemroaya dkk., 2011; Karami dkk., 2015). Demikian pula dengan MUFA juga mengalami peningkatan meskipun tidak terlalu signifikan. Hal ini disebabkan PUFA dan asam lemak tak jenuh tunggal beraksi SFA.

Aranda dkk, (2005) menyatakan bahwa oksidasi PUFA dimulai dengan produksi hidrogen-peroksida dengan tiga cara yang berbeda: (1) autooksidasi, (2) oksidasi enzimatik, dan (3) fotooksidasi, yang juga bisa terjadi secara bersamaan. Produk peroksida terurai dengan mekanisme yang berbeda, membentuk produk oksidasi sekunder; kedua produk oksidasi sekunder dan primer dapat bereaksi dengan gugus amino protein, menghasilkan senyawa interaksi yang memodifikasi rasa, bau dan sifat fungsional dari protein. Selanjutnya, fraksi volatil senyawa ini diindikasikan sebagai penyebab 
Tabel 2. Komposisi asam lemak fillet ikan kakap (Lutjanus sp) selama penyimpanan

Suhu dan lama penyimpanan (hari)

\begin{tabular}{|c|c|c|c|c|c|}
\hline Profil asam lemak (\%) & $0^{\circ} \mathrm{C} / 45$ & $10^{\circ} \mathrm{C} / 27$ & $20^{\circ} \mathrm{C} / 9$ & $30^{\circ} \mathrm{C} / 4,5$ & $40{ }^{\circ} \mathrm{C} / 2,25$ \\
\hline Asam laurat & nd & $0,70 \pm 0,01$ & nd & nd & $0,99 \pm 0,01$ \\
\hline Asam tridekanoat & nd & $0,001 \pm 0,01$ & nd & nd & $0,86 \pm 0,01$ \\
\hline Asam meristat & $0,74 \pm 0,01$ & $4,69 \pm 0,02$ & $0,51 \pm 0,01$ & $4,44 \pm 0,03$ & $2,69 \pm 0,01$ \\
\hline Asam pentadekanoat & $0,90 \pm 0,02$ & $0,001 \pm 0,01$ & $0,38 \pm 0,01$ & $1,03 \pm 0,01$ & $2,46 \pm 0,02$ \\
\hline Asam palmitat & $1,67 \pm 0,04$ & $2,28 \pm 0,03$ & $12,94 \pm 0,07$ & $4,39 \pm 0,07$ & $36,58 \pm 0,15$ \\
\hline Asam stearat & nd & $0,71 \pm 0,01$ & $12,14 \pm 0,08$ & $9,19 \pm 0,09$ & $15,46 \pm 0,15$ \\
\hline Asam heneikosanoat & nd & $13,46 \pm 0,05$ & nd & $0,78 \pm 0,01$ & $2,03 \pm 0,01$ \\
\hline Asam behenat & $1,04 \pm 0,02$ & nd & $1,54 \pm 0,03$ & $0,65 \pm 0,01$ & $0,68 \pm 0,01$ \\
\hline Asam lignoserat & nd & $0,76 \pm 0,01$ & $0,55 \pm 0,01$ & $0,74 \pm 0,01$ & nd \\
\hline Asam heptadekanoat & nd & $17,81 \pm 0,10$ & nd & $1,96 \pm 0,02$ & nd \\
\hline Asam arakidat & nd & $2,95 \pm 0,02$ & nd & nd & nd \\
\hline Asam lemak jenuh (SFA) & 4,35 & 25,552 & 28,06 & 32,73 & 61,75 \\
\hline Asam oleat & $12,63 \pm 0,15$ & $8,81 \pm 0,07$ & $10,82 \pm 0,09$ & $16,37 \pm 0,15$ & $22,70 \pm 0,20$ \\
\hline Asam nervonat & $1,34 \pm 0,02$ & $1,64 \pm 0,04$ & nd & $1,03 \pm 0,02$ & $1,27 \pm 0,01$ \\
\hline Asam palmitoleat & $2,59 \pm 0,03$ & $13,24 \pm 0,08$ & nd & nd & nd \\
\hline Asam erucat & $5,43 \pm 0,06$ & nd & $3,58 \pm 0,09$ & $5,26 \pm 0,06$ & $5,43 \pm 0,05$ \\
\hline Asam eikosanoat & $8,34 \pm 0,10$ & $0,001 \pm 0,01$ & nd & nd & nd \\
\hline Asam lemak tak jenuh tunggal (MUFA) & 23,72 & 23,687 & 14,4 & 22,66 & 29,4 \\
\hline Asam eikosatetranoat & nd & nd & nd & $1,05 \pm 0,01$ & $5,60 \pm 0,08$ \\
\hline Asam dokosadinoat & $0,83 \pm 0,01$ & $0,43 \pm 0,01$ & nd & $0,70 \pm 0,01$ & nd \\
\hline Asam eikosapentanoat & $6,06 \pm 0,09$ & $2,29 \pm 0,04$ & $3,52 \pm 0,07$ & nd & $0,43 \pm 0,01$ \\
\hline Asam eikosatrienoat & $1,56 \pm 0,03$ & $9,82 \pm 0,15$ & $2,6,23 \pm 0,04$ & nd & nd \\
\hline Asam arakidonat & $0,69 \pm 0,02$ & nd & nd & nd & nd \\
\hline Asam dokosaheksanoat & $5,31 \pm 0,09$ & $0,17 \pm 0,01$ & nd & nd & $0,25 \pm 0,01$ \\
\hline Asam linolenat & $10,61 \pm 0,10$ & $3,27 \pm 0,02$ & $1,52 \pm 0,02$ & $3,57 \pm 0,03$ & $2,56 \pm 0,02$ \\
\hline Asam lemak tak jenuh majemuk (PUFA) & 25,06 & 15,98 & 14,99 & 10,32 & 8,84 \\
\hline
\end{tabular}

Keterangan: nilai yang diperoleh berasal dari rata-rata 2 kali ulangan, nd: not detected

ketengikan dalam ikan berlemak (Aranda dkk., 2005). Shahidi dan Miraliakbari (2004) menyatakan bahwa ikan berlemak mengandung $\omega-3$ (PUFA), seperti asam eikosapentanoat

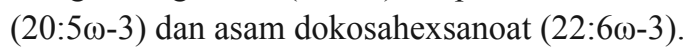

Sebecic dan Beutelspacher (2005) menyatakan bahwa oksidasi merupakan proses kerusakan lemak dan mengakibatkan terbentuknya senyawa off flavor dan konsidi ini disebut tengik (rancid). Produk pangan olahan yang tengik dapat mengalami perubahan warna dan kehilangan nilai gizi karena oksidasi asam lemak tak jenuh (PUFA) yang berdampak pada penurunan mutu. Senyawa hasil oksidasi seperti peroksida, aldehid, dan keton berbahaya terhadap kesehatan manusia. Sedangkan McClement dan Decker (2000) menyatakan faktor-faktor yang mempengaruhi kecepatan oksidasi antara lain jumlah dan jenis oksigen, struktur kimia lipida, keberadaan senyawa antioksidan dan prooksidan, suhu penyimpanan dan sifat bahan pengemas.

\section{Angka Peroksida pada Suhu dan Lama Penyimpanan}

Angka peroksida sebagai produk primer dari oksidasi fillet ikan kakap selama penyimpanan pada berbagai suhu dan waktu dapat dilihat pada Tabel 3 . 
Tabel 3. Data analisis angka peroksida fillet ikan kakap selama penyimpanan*

\begin{tabular}{|c|c|c|}
\hline Suhu & $\begin{array}{c}\text { Lama } \\
\text { penyimpanan (hari) }\end{array}$ & $\begin{array}{l}\text { Angka peroksida } \\
\text { (meq/kg sampel) }\end{array}$ \\
\hline \multirow{10}{*}{$0^{\circ} \mathrm{C}$} & 0 & $1,74 \pm 0,11$ \\
\hline & 5 & $2,94 \pm 0,25$ \\
\hline & 10 & $4,06 \pm 0,10$ \\
\hline & 15 & $5,30 \pm 0,09$ \\
\hline & 20 & $6,78 \pm 0,10$ \\
\hline & 25 & $6,29 \pm 0,28$ \\
\hline & 30 & $10,91 \pm 0,09$ \\
\hline & 35 & $11,92 \pm 0,12$ \\
\hline & 40 & $12,98 \pm 0,02$ \\
\hline & 45 & $13,22 \pm 0,56$ \\
\hline \multirow{10}{*}{$10^{\circ} \mathrm{C}$} & 0 & $1,74 \pm 0,11$ \\
\hline & 3 & $3,27 \pm 0,29$ \\
\hline & 6 & $5,64 \pm 0,35$ \\
\hline & 9 & $6,90 \pm 0,22$ \\
\hline & 12 & $6,39 \pm 0,24$ \\
\hline & 15 & $9,60 \pm 0,02$ \\
\hline & 18 & $10,79 \pm 0,20$ \\
\hline & 21 & $10,49 \pm 0,06$ \\
\hline & 24 & $14,52 \pm 0,02$ \\
\hline & 27 & $15,10 \pm 0,20$ \\
\hline \multirow{10}{*}{$20^{\circ} \mathrm{C}$} & 0 & $1,74 \pm 0,11$ \\
\hline & 1 & $4,22 \pm 0,78$ \\
\hline & 2 & $6,96 \pm 0,26$ \\
\hline & 3 & $8,37 \pm 0,11$ \\
\hline & 4 & $8,51 \pm 0,47$ \\
\hline & 5 & $11,22 \pm 0,17$ \\
\hline & 6 & $11,96 \pm 0,01$ \\
\hline & 7 & $15,60 \pm 0,49$ \\
\hline & 8 & $15,96 \pm 0,12$ \\
\hline & 9 & $18,07 \pm 0,09$ \\
\hline \multirow{10}{*}{$30^{\circ} \mathrm{C}$} & 0 & $1,74 \pm 0,11$ \\
\hline & 0,5 & $4,57 \pm 0,10$ \\
\hline & 1 & $7,07 \pm 0,26$ \\
\hline & 1,5 & $9,28 \pm 0,13$ \\
\hline & 2 & $10,42 \pm 0,34$ \\
\hline & 2,5 & $12,14 \pm 0,10$ \\
\hline & 3 & $11,83 \pm 0,08$ \\
\hline & 3,5 & $16,97 \pm 0,11$ \\
\hline & 4 & $18,70 \pm 0,09$ \\
\hline & 4,5 & $20,41 \pm 0,08$ \\
\hline
\end{tabular}

\begin{tabular}{|c|c|c|}
\hline Suhu & $\begin{array}{c}\text { Lama } \\
\text { penyimpanan (hari) }\end{array}$ & $\begin{array}{l}\text { Angka peroksida } \\
\text { (meq/kg sampel) }\end{array}$ \\
\hline \multirow{10}{*}{$40^{\circ} \mathrm{C}$} & 0 & $1,74 \pm 0,11$ \\
\hline & 0,25 & $4,68 \pm 0,32$ \\
\hline & 0,5 & $7,78 \pm 0,13$ \\
\hline & 0,75 & $10,72 \pm 0,23$ \\
\hline & 1 & $12,07 \pm 0,36$ \\
\hline & 1,25 & $12,66 \pm 0,01$ \\
\hline & 1,5 & $18,42 \pm 0,09$ \\
\hline & 1,75 & $18,42 \pm 0,05$ \\
\hline & 2 & $22,93 \pm 0,04$ \\
\hline & 2,25 & $24,63 \pm 0,07$ \\
\hline
\end{tabular}

*Keterangan: Data berasal dari 3x ulangan

Pada perlakuan penyimpanan suhu beku $\left(0{ }^{\circ} \mathrm{C}\right)$ memperlihatkan angka peroksida sampai 45 hari penyimpanan. Angka peroksida meningkat 7,6 kali pada suhu $0{ }^{\circ} \mathrm{C}$ dengan peningkatan suhu penyimpanan, sedangkan pada suhu 10, 20, 30, dan $40{ }^{\circ} \mathrm{C}$ angka peroksida meningkat masing-masing menjadi $8,70,10,40,11,70$, dan 14,60 kali meq/kg sampel dengan peningkatan suhu penyimpanan. Angka peroksida meningkat dari suhu $0 \mathrm{ke}$ suhu $40{ }^{\circ} \mathrm{C}$ dengan peningkatan lama penyimpanan dari satu hari sampai 45 hari lama penyimpanan. Peningkatan primer peroksida fillet ikan kakap semakin tinggi dengan kenaikan suhu penyimpanan dari $0{ }^{\circ} \mathrm{C}$ sampai $40{ }^{\circ} \mathrm{C}$.

Menurut Pak dkk. (2005) angka peroksida merupakan indikator stabilitas minyak terhadap oksidasi, dengan parameter produk oksidasi primer lipida yaitu hidroperoksida. Reaksi oksidasi lipida/minyak secara natural mudah terjadi, sebab lemak fillet ikan kakap kaya PUFA (6 ikatan rangkap), sedangkan lemak yang mengandung banyak ikatan rangkap mudah mengalami reaksi oksidasi lipida.

\section{Angka TBA pada Suhu dan Lama Penyimpanan}

Angka TBAdigunakan untuk mengukur produk sekunder dari oksidasi lipida terutama yang berasal dari PUFA (Semb, 2012) dan menunjukkan tingkat ketengikan khususnya pada lemak yang mengandung PUFA tinggi (Cheng dkk. 2014). Angka TBA sebagai produk sekunder oksidasi fillet ikan kakap selama penyimpanan dapat dilihat pada Tabel 4. Angka TBA meningkat 6,30 kali pada suhu $0{ }^{\circ} \mathrm{C}$ dengan adanya peningkatan suhu penyimpanan, sedangkan pada suhu 10, 20, 30, dan $40^{\circ} \mathrm{C}$ angka TBA meningkat masing-masing menjadi 7,50, 8,80, 9,50, dan 10,2 kali mg MDA/kg sampel dengan peningkatan suhu penyimpanan. Angka TBA meningkat dari suhu 0 ke suhu $40^{\circ} \mathrm{C}$ dengan peningkatan lama penyimpanan dari satu hari sampai 45 hari lama penyimpanan. 
Tabel 4. Data analisis angka TBA fillet ikan kakap selama penyimpanan*

\begin{tabular}{|c|c|c|}
\hline Suhu & $\begin{array}{c}\text { Lama } \\
\text { penyimpanan (hari) }\end{array}$ & $\begin{array}{c}\text { Angka TBA } \\
\text { (mg MDA/kg sampel) }\end{array}$ \\
\hline \multirow{10}{*}{$0^{\circ} \mathrm{C}$} & 0 & $2,31 \pm 0,21$ \\
\hline & 5 & $3,50 \pm 0,12$ \\
\hline & 10 & $5,28 \pm 0,21$ \\
\hline & 15 & $6,57 \pm 0,34$ \\
\hline & 20 & $6,32 \pm 0,20$ \\
\hline & 25 & $9,57 \pm 0,02$ \\
\hline & 30 & $11,91 \pm 0,50$ \\
\hline & 35 & $11,75 \pm 0,10$ \\
\hline & 40 & $13,72 \pm 0,46$ \\
\hline & 45 & $14,63 \pm 0,04$ \\
\hline \multirow{10}{*}{$10^{\circ} \mathrm{C}$} & 0 & $2,31 \pm 0,21$ \\
\hline & 3 & $4,30 \pm 0,28$ \\
\hline & 6 & $6,75 \pm 0,17$ \\
\hline & 9 & $6,11 \pm 0,01$ \\
\hline & 12 & $10,76 \pm 0,02$ \\
\hline & 15 & $13,41 \pm 0,20$ \\
\hline & 18 & $13,29 \pm 0,38$ \\
\hline & 21 & $15,61 \pm 0,45$ \\
\hline & 24 & $16,80 \pm 0,02$ \\
\hline & 27 & $17,23 \pm 0,02$ \\
\hline \multirow{10}{*}{$20^{\circ} \mathrm{C}$} & 0 & $2,31 \pm 0,21$ \\
\hline & 1 & $4,42 \pm 0,68$ \\
\hline & 2 & $6,20 \pm 0,40$ \\
\hline & 3 & $6,93 \pm 0,09$ \\
\hline & 4 & $10,80 \pm 0,15$ \\
\hline & 5 & $13,34 \pm 0,15$ \\
\hline & 6 & $13,46 \pm 0,56$ \\
\hline & 7 & $17,74 \pm 0,03$ \\
\hline & 8 & $18,62 \pm 0,59$ \\
\hline & 9 & $20,32 \pm 0,12$ \\
\hline \multirow{10}{*}{$30^{\circ} \mathrm{C}$} & 0 & $2,31 \pm 0,21$ \\
\hline & 0,5 & $5,99 \pm 0,10$ \\
\hline & 1 & $7,59 \pm 0,46$ \\
\hline & 1,5 & $8,93 \pm 0,77$ \\
\hline & 2 & $8,77 \pm 0,20$ \\
\hline & 2,5 & $13,85 \pm 0,09$ \\
\hline & 3 & $14,51 \pm 1,44$ \\
\hline & 3,5 & $14,59 \pm 0,48$ \\
\hline & 4 & $20,73 \pm 0,29$ \\
\hline & 4,5 & $22,03 \pm 0,71$ \\
\hline
\end{tabular}

\begin{tabular}{crc}
\hline Suhu & $\begin{array}{c}\text { Lama } \\
\text { penyimpanan (hari) }\end{array}$ & $\begin{array}{r}\text { Angka peroksida } \\
\text { (meq/kg sampel) }\end{array}$ \\
\hline 0 & $2,31 \pm 0,21$ \\
0,25 & $5,98 \pm 0,09$ \\
$40{ }^{\circ} \mathrm{C}$ & 0,5 & $7,95 \pm 0,92$ \\
& 0,75 & $8,19 \pm 0,21$ \\
1 & $8,55 \pm 0,37$ \\
1,25 & $10,80 \pm 2,67$ \\
1,5 & $15,44 \pm 0,55$ \\
1,75 & $15,59 \pm 0,01$ \\
2 & $20,53 \pm 0,58$ \\
2,25 & $23,57 \pm 0,49$ \\
\hline
\end{tabular}

*Keterangan : data berasal dari $3 x$ ulangan

\section{KESIMPULAN}

Kandungan lemak ikan sangat dipengaruhi oleh kesegaran ikan. Fillet ikan kakap memiliki asam lemak jenuh yang terdiri dari asam laurat, asam tridekanoat, asam meristat, asam pentadekanoat, asam palmitat, asam stearat, asam heneikosanoat, asam behenat, asam lignocerat, asam heptadekanoat dan asam arakhidat. Asam lemak tak jenuh tunggal terdiri dari asam oleat, asam nervonat, asam palmitoleat, asam erucat, dan asam eikosanoat, sedangkan asam lemak tak jenuh majemuk terdiri dari: asam eikosatetranoat, asam dokosadinoat, asam eikosapentanoat, asam eikosatrioanat, asam arakidonat, dan asam linolenat yang rentan terhadap kerusakan oksidatif.

Angka peroksida meningkat 9,6 kali pada suhu $0{ }^{\circ} \mathrm{C}$ dengan peningkatan suhu penyimpanan, sedangkan pada suhu $10,20,30$, dan $40{ }^{\circ} \mathrm{C}$ angka peroksida meningkat masing-masing menjadi 14,33, 16,12, 19,19, dan 23,05 kali $\mathrm{meq} / \mathrm{kg}$ sampel dengan peningkatan suhu penyimpanan. Angka TBA meningkat 6,3 kali pada suhu $0{ }^{\circ} \mathrm{C}$ dengan adanya peningkatan suhu penyimpanan, sedangkan pada suhu $10,20,30$, dan $40{ }^{\circ} \mathrm{C}$ angka peroksida meningkat masingmasing menjadi 7,50, 8,80, 9,50, dan 10,20 kali mg MDA/kg sampel dengan peningkatan suhu penyimpanan.

\section{DAFTAR PUSTAKA}

Adnan, M. (1980). Lipid Properties and Stability of Partially Defatted Peanuts. Doctor Thesis, Department of Food Science, University of Illinois, Urbana-Champaign.

AOAC. (2006). Official Methods of Analysis of the Association of Official Analytical Chemistry", Association of Official Analysis Chemistry, Washington, $D C$. 
Aranda, M., Mendoza, N. dan Villegas, R. (2005). Lipid damage during frozen storage of whole jack mackerel (Trachurrus symmetricus Murphyi). Journal of Food Lipids 13: 155-166.

Badii, F. dan Howell, N.K. (2012). Changes in the texture and structure of cod and haddock fillets during frozen storage. Food Hydrocolloids 16(4): 313-319.

Bayir, A. dan Sirkecioglu, A.N. (2006). Fatty acid composition in some selected marine fish species living in Turkish water. Journal of Science and Food Agriculture 86: 163-168.

Benjakul, S., Viessanguan, W., Thongkaew, C. dan Tanaka, M. (2005). Effect of frozen storage on chemical and gel-forming properties of fish commonly used for surimi production in Thailand. Food Hydrocolloids 19(2): 197-207.

Boran, G., Karach dan Boran, M. (2006). Changes in the quality of fish oils due to storage temperature and time. Food Chemistry 98: 693-698.

Chaijan, M., Benjakul, S., Visessanguan, W. dan Faustman, C. (2006). Changes of lipids in sardine (Sardinella gibbosa) muscle during iced storage. Food Chemistry 99: 81-83.

Cheng, J.H., Sun, D.W., Pu, H.B., Wang, Q.J., Chen, Y.N. (2014). Suitabilility of hyperspectral imaging for rapid evaluation of thiobarbituric acid (TBA) value in grass carp (Ctenopharyngodon idella) fillet. Food Chemistry 171: $258-265$.

de Castro, F.A.F., Sant'Ana a, P.M.H., Campos, M.F., Costa, B.M.N., Silva, C.T.M., Salaro, L.A. dan Franceschini, C.D.S. (2007). Fatty acid composition of three freshwater fishes under different storage and cooking processes. Food Chemistry 103: 1080-1090.

Dragoev, S.G., Kiosev, D.D., Danchev, S.A., Ioncheva, N.I. dan Genov, N.S. (2008). Study on the oxidative processes in frozen fish. Journal of Agriculture and Science 4: 55-65.

Fijuwara, K., Oosawa, T. dan Saeki, H. (2008). Improved thermal stability and emulsifying proper-Ties of carp myofibrillar proteins by conjunction with dextran. Journal of Agricultural and Food Chemistery 46: 1257-1261.

Karami, B., Moradi, Y., Motallebi, A.A., Hosseini, E. dan Soltani, M. (2015). Effects of frozen storage on fatty acids profile, chemical quality indices and sensory properties of red tilapia (Oreochromis niloticus $\times$ Tilapia mosambicus) fillets. Iranian Journal of Fisheries Sciences 12: 378-388.

Kolbe, E., Craven, C., Sylvia, G. dan Morrissey, M. (2004). Chilling and freezing guidelines to Maintain Onboard Quality and Safety of Albacore Tuna Agricultural Experiment Station. Oregon State University, Astoria, Oregon, USA.

McClements, D.J. dan Decker, E.A. (2000). Lipid oxidation in oil-in-water emulsions: Impact of moleculer enviroment on chemical reaction in heterogenous food system. Journal of Food Science 65: 1270-1282.

Nazemroaya, S., Sahari, A.M. dan Rezaei, M. (2009). Effect of frozen storage on fatty acid composition and changes in lipid content of Scomberomorus ommersoni and Carcharhinus dussumieri. Journal Application Ichthyology 25: 91-95.

Okada, M. (2010). Fish and Raw Material. In science of processing marine food product. Vol. I. editor. T. Motohiro, H. Kadota. K. Hashimoto. M. Katayama and T. Tokunaga. Japan International Coorporation Agency. Hyoga International Centre Japan.

Pak, C.S. (2005). Stability and Quality of Fish Oil during Typical Domestic Application. Fisheries Training Progamme, The United Nations University, Iceland.

Pazos, M., Gallardo, J.M., Torres, J.L. dan Medina, I. (2005). Activity of grape polyphenols as inhibitors of the oxidation of fish lipids and frozen fish muscle. Food Chemistry 92: 547-557.

Persson, P.O. dan Londahl, G. (2013). Freezing technology. Dalam: Mallet, C.P. (Ed.). Frozen Food Technology. Blackie Academic and Professional, Glasgow, UK.

Pirestani, S., Sahari, M.A. dan Barzegar, M. (2010). Fatty acids changes during frozen storage in several fish species from South Caspian Sea. Journal Agricutural Science and Technology 12: 321-329.

Pourashouri, P., Shabanpour, B., Aubourg, S.P., Rohi, J.D. dan Shabani, A. (2009). Aninvestigation of rancidity inhibition during frozen storage of Wels catfish (Silurus glanis) fillets by previous ascorbic and citric acid treatment. International Journal of Food Science and Technology 44: 1503-1509.

Quitral, V., Donoso, M.L., Ortiz, J., Herrera, M.V., Araya, H. dan Aubourg, S.P. (2009). Chemical changes during the chilled storage of Chilean jack mackerel (Trachurus murphyi): Effect of a plant-extract icing system. $L W T$ Food Science and Technology 42: 1450-1454. 
Richards, M.P. dan Hultin, H.O. (2012). Contributions of blood and blood components to lipid oxidation in fish muscle. Journal Agriculture Food Chemistry 50: 555564.

Sarma, J., Reddy, G.V.S. dan Srikar, L.N. (2000). Effect of frozen storage on lipids and functional properties of proteins of dressed Indian oil sardine (Sardinella longiceps). Food Research International 33: 815-820.

Secbecic, N. dan Beutelspecher, S.C. (2005). Anti-oxidative vitamins perevent lipid-peroxidation and apoptosisi in corneal endotheliel cell. Cell Tissue Respirative 320: $465-475$.

Semb, T.N. (2012). Analytical Methods for Determination of The Oxidative Status in Oils. Department of Biotechnology, Norwegian University of Science and Technology.
Seed, S. dan Howell, N.K. (2002). Effect of lipid oxidation and frozen storage on muscle proteins of Atlantic mackeral. Journal of the Science of Food and Agriculture 82: 579-586.

Shahidi, F. dan Miraliakkbari (2004). Omega-3 fatty acid composition and stability of seal lipids. Lipid in Food Flavors 16: 233-243.

Shaviklo, G.R. (2006). Quality Assessment of Ash Protein Isolates Using Surim Standard Methods. Reykjavik. The United Nations University, Ice/and.

Tokur, B. dan Korkmaz, K. (2007). The effects of an ironcatalyzed oxidation system on lipids and proteins of dark muscle fish. Food Chemistry 104: 754-760.

Yerlikaya, P. dan Gokoglu, N. (2010). Inhibitation effects of green tea and grape seed extract on lipid oxidation ini bonito fillet during frozen storage. International Journal of Food Science and Technology 45: 252-257. 